\title{
Zircons from eclogite in the Jericho Kimberlite Pipe, northern Canada: Evidence for Proterozoic High Pressure Metamorphism Beneath the Slave Province
}

\author{
Heaman, Larry M. ${ }^{1}$, Creaser, Robert A. ${ }^{1}$ and Cookenboo, Harrison O. ${ }^{2}$ \\ ${ }^{1}$ Dept. of Earth and Atmospheric Sciences, University of Alberta, Edmonton, Alberta, Canada T6G 2E3 \\ ${ }^{2}$ Canamera Geological Ltd., North Vancouver, British Columbia, Canada V7J 1G4
}

Eclogite xenoliths are abundant in the Jericho kimberlite of the Slave craton in northern Canada (Kopylova et al., this volume; Cookenboo et al., this volume), including a small proportion (2 to $3 \%$ out of a collection of 206 eclogites) that contain zircon. Although zircon-bearing eclogite xenoliths have been reported from a few orthogneiss localities, where both the timing of protolith formation and high pressure metamorphism are recorded in the U-Pb zircon systematics (e.g. Peucat et al., 1982; Paquette et al., 1985; 1995), zircon-bearing eclogites entrained in kimberlites are extremely rare (e.g. Chen et al., 1994). U-Pb systematics in most zircon-bearing eclogites from Jericho reveal unusual diffusional $\mathrm{Pb}$-loss characteristics that point to Proterozoic high pressure metamorphism beneath the Slave craton. A single zircon-bearing eclogite that experienced episodic Pb-loss provides a preliminary Proterozoic age for the metamorphism, and supports the Jericho kimberlite emplacement age of $172 \pm 2 \mathrm{Ma}$ as previously reported from preliminary $\mathrm{Rb}-\mathrm{Sr}$ studies of phlogopite (Heaman et al., 1997). In order to more precisely constrain the kimberlite emplacement age and the timing of Proterozoic metamorphism, we describe in this report: 1) the U-Pb systematics of the zircon-bearing eclogites; 2) recent $\mathrm{Rb}-\mathrm{Sr}$ results from phlogopite; and 3) initial Sm-Nd results from garnet and clinopyroxene separates from Jericho eclogite.

\section{GEOLOGICAL SETTING}

The Jericho kimberlite (JD-1) is a diamondiferous pipe that intrudes ca. $2.6 \mathrm{Ga}$ and older Archean granitoid rocks of the central Slave craton, approximately $150 \mathrm{~km}$ north of the main cluster of pipes located near the Lac de Gras, and $400 \mathrm{~km}$ northwest of Yellowknife, Northwest Territories. Four other kimberlites including the JD-3 pipe, $7 \mathrm{~km}$ southwest of Jericho, have been discovered in the area and all apparently belong to a single kimberlite field spatially separated from pipes near Lac de Gras (Cookenboo et al., 1998). In addition to mantle xenoliths, the pipes in the Jericho kimberlite field entrained a distinctive population of crustal xenoliths which provide some geologic constraint to the emplacement age independent of radiometric dates. Most importantly, Middle Devonian (late Eifelian and early Givetian age) limestones that were deposited between approximately 375 to 385 $\mathrm{Ma}$ (Cookenboo et al., in press) provide a maximum geologic age for the pipe. More tenuously, the lack of wood fragments and Upper Cretaceous to Lower Tertiary mudstones at Jericho, which are common in the pipes near Lac de Gras (Nassichuk and McIntyre, 1996), implies a minimum emplacement age of pre-Late Cretaceous (roughly $100 \mathrm{Ma}$ ).

\section{$\mathrm{Rb}-\mathrm{Sr}$ emplacement age from phlogopite}

We have obtained a total of eight $\mathrm{Rb}-\mathrm{Sr}$ phlogopite analyses from various material, including five analyses from three macrocrysts hand-picked from kimberlite (four from JD-1 and one from JD3); two analyses from different eclogite xenoliths (both from JD-1) and a single analysis from a peridotite xenolith from JD-3. The selected phlogopite macrocrysts were fresh crystals generally devoid of visible inclusions or alteration. The majority of fractions were given a dilute $(0.75 \mathrm{~N})$ warm $\mathrm{HCl}$ leach prior to dissolution following the rationale of Brown et al. (1989). Phlogopite macrocrysts from kimberlite and the peridotite xenolith typically have high ${ }^{87} \mathrm{Rb} /{ }^{86} \mathrm{Sr}$ ratios $(>180)$ with correspondingly high $\mathrm{Rb}$ concentrations (up to $885 \mathrm{ppm}$ ), whereas phlogopite analyses from the two eclogite xenoliths have much lower ${ }^{87} \mathrm{Rb} /{ }^{86} \mathrm{Sr}$ ratios $(<50)$, primarily a consequence of much higher $\mathrm{Sr}$ contents (18-24 ppm). Most of the Rb-Sr analyses are collinear with the exception of the peridotite 
and one eclogite (MX1) xenolith which plot below a reference isochron. Excluding the xenolith phlogopite analyses, the kimberlite phlogopite macrocrysts define an isochron age of $171.9 \pm 2.6 \mathrm{Ma}$ $(2 \sigma)$ with an initial strontium ratio of $0.7086 \pm 0.0098$ (MSWD=0.84). Considering the excellent fit of these kimberlitic phlogopite analyses to a single isochron, the $172 \mathrm{Ma}$ age is interpreted to represent the best estimate for the time of kimberlite emplacement at Jericho. In fact, treating the JD-1 and JD3 data independently indicates that the emplacement ages for both samples are indistinguishable within about $1 \mathrm{~m} . y$. Interestingly, including the phlogopite analysis from one of the eclogite xenoliths (MX14) results in a very precise age of $173 \pm 1 \mathrm{Ma}$ age with an initial strontium ratio of $0.7039 \pm 0.015$ (MSWD=0.87) however these results could be misleading as there is evidence that the xenolith and kimberlite phlogopites do not have identical initial strontium ratios. If the $172 \pm 3 \mathrm{Ma} \mathrm{Rb}-\mathrm{Sr}$ kimberlitic phlogopite age result obtained here is an accurate estimate of timing of Jericho kimberlite magmatism, then the Jericho pipes represent the first documented examples of mid-Jurassic kimberlite magmatism in the Slave Province.

\section{$\mathrm{U}-\mathrm{Pb}$ systematics of zircon from eclogite}

The U-Pb results for single zircon crystals extracted from five eclogite xenoliths are in progress. The eclogitic zircon grains investigated so far generally have lower uranium abundances (10-70 ppm) compared to zircon from eclogite xenoliths within orthogneiss (100-300 ppm; e.g. Peucat et al., 1982). In detail, there are two distinct geochemical patterns preserved in the Jericho eclogitic zircon which are best seen on a plot of Th/U versus uranium content. The first pattern displays a strong inverse correlation between uranium content and $\mathrm{Th} / \mathrm{U}$ ratio and occurs in moderate uranium level (>45 ppm) zircon grains analysed from xenoliths MX1 and MX10. In contrast, lowuranium (9-33 ppm) zircon crystals from two other eclogite xenoliths (MX8 and MX12) generally have very uniform $\mathrm{Th} / \mathrm{U}$ ratios.

The U-Pb zircon results, for the most part, are unusual and do not define simple discordia or mixing lines. All the analyses are highly discordant (39-69\%) and there is a large range in model ${ }^{207} \mathrm{~Pb} /{ }^{206} \mathrm{~Pb}$ ages for zircon suites from individual xenoliths. The most extreme range in ${ }^{207} \mathrm{~Pb} /{ }^{206} \mathrm{~Pb}$ ages was obtained for xenolith MX10 (403-1561 Ma). Of the five eclogite xenoliths analysed, only the zircon analyses from MX10 closely approach a linear relationship where three of four analyses define a regression line with an upper intercept age of $1679 \pm 10 \mathrm{Ma}$ and a lower intercept age of $178 \pm 5 \mathrm{Ma}(37 \%$ probability of fit), within error of the kimberlite emplacement age of $172 \pm 3 \mathrm{Ma}$ established from Rb-Sr kimberlitic phlogopite analyses.

\section{Sm-Nd from eclogite garnet and clinopyroxene separates}

The Sm-Nd isotopic composition of the eclogite xenoliths is currently under investigation to provide an independent estimate for the timing of eclogite metamorphism. The preliminary garnetclinopyroxene Sm-Nd results from one eclogite xenolith indicates an age of $216 \mathrm{Ma}$ with an epsilon

$\mathrm{Nd}$ value of -5.5. At present, it is unclear whether this age has geological significance or represents partial equilibration of the Sm-Nd system in the xenoliths at the time of entrainment as has been documented previously by Richardson et al. (1985) for Bultfontein garnet lherzolite xenoliths. The older depleted mantle model age for the clinopyroxene of $1.97 \mathrm{Ga}$ could be support for Paleoproterozoic eclogite metamorphism as discussed below.

\section{DISCUSSION}

The $\mathrm{Rb}-\mathrm{Sr}$ results for phlogopite macrocrysts from kimberlite define an age of $172 \pm 3 \mathrm{Ma}$ which is interpreted as the best estimate for the emplacement age of both the JD-1 and JD-3 pipes. These results also document for the first time the presence of Middle Jurassic kimberlite magmatism in the Slave Province, Canada which is distinct from Jurassic kimberlite magmatism elsewhere in North America (e.g. 155-160 Ma Kirkland Lake/Timiskaming field, Heaman and Kjarsgaard, 1998). 
The U-Pb systematics of zircon isolated from eclogite xenoliths entrained in JD-1 indicate an unusual behaviour. Three of the four xenoliths investigated in detail do not display a linear relationship and record either a complicated multi-stage $\mathrm{Pb}$-loss history or represent paleo-diffusion curves such as those described by Peucat et al. (1982). In the latter case, combining the U-Pb zircon results obtained here with geothermometry data for the eclogite xenoliths could provide a natural example and indirect estimate for the closure temperature for $\mathrm{Pb}$ diffusion in zircon. The lower intercept age of $178 \pm 5 \mathrm{Ma}$ for the mixing line obtained for zircon from xenolith MX10 is within error of the $172 \pm 3 \mathrm{Ma}$ emplacement age obtained using $\mathrm{Rb}-\mathrm{Sr}$ phlogopite macrocrysts and provides independent confirmation of the Middle Jurassic emplacement age. The U-Pb zircon data also indicate that a significant amount of $\mathrm{Pb}$-loss in the zircon crystals occurred at the time of kimberlite emplacement. The upper intercept age of $1679 \mathrm{Ma}$ for xenolith MX10 is intriguing and could be interpreted in at least two ways: 1) the upper intercept age could be interpreted as the protolith age for the eclogite precursor (as in the case for eclogitic pods in orthogneiss); or 2) the $1679 \mathrm{Ma}$ age may reflect a minimum estimate for the time of zircon growth during eclogite metamorphism. The large size of the zircon crystals (up to $3 \mathrm{~mm}$ ), their low uranium content ( $<70 \mathrm{ppm}$ ) and low $\mathrm{Th} / \mathrm{U}$ ratio $(<0.2)$ are not typical of primary magmatic zircon crystallizing in mafic magmas (e.g. Bossart et al., 1986) and so we discount the first explanation, and favour the second alternative that the 1679 Ma reflects a minimum age for the timing of eclogite metamorphism. The origin of Paleoproterozoic eclogites under the Slave craton remains enigmatic, but could derive from east-dipping oceanic crust subducted beneath the western Slave craton during Great Bear Magmatic Arc time (1.88-1.84 Ga).

\section{REFERENCES}

Chen, Y.D., O'Reilly, S.Y., Kinny, P.D., and Griffin, W.L., 1994. Dating lower crust and upper mantle events: an ion microprobe study of xenoliths from kimberlitic pipes, South Australia: Lithos, 32, p. 77-94.

Cookenboo, H. O., Dupuis, J., and Foulkes J., 1998. Discovery and evaluation of the Jericho and 5034 kimberlite fields in the Slave Craton, northern Canada: Pathways'98. Extended Abstract Volume, p. 166-169.

Cookenboo, H. O., Kopylova, M. G., and Daoud, D.K. (this volume) A chemically and texturally distinct layer of diamondiferous eclogite beneath the central Siave craton, northern Canada.

Bossart, P.J., Meier, M., Oberli, F., and Steiger, R.H., 1986. Morphology versus U-Pb systematics in zircon: a highresolution isotopic study of zircon population from a Variscan dike in Central Alps: Earth and Planetary Science Letters, 78, p. 339-354.

Brown, R.W., Allsopp, H.L., Bristow, J.W., \& Smith, C.B., 1989. Improved precision of Rb-Sr dating of kimberlitic micas: an assessment of a leaching technique: Chemical Geology, 79, p. 125-136.

Heaman, L.M., Kjarsgaard, B.A., Creaser, R.A., Cookenboo, H.O., and Kretschmar, U., 1997. Multiple episodes of kimberlite magmatism in the Slave Province, North America: Lithoprobe Workshop Report No. 56, p. 14-17.

Heaman, L.M. and Kjarsgaard, B., 1995. Episodic nature of North American kimberlite magmatism: support for a global triggering mechanism: (Submitted to J. Petrology).

Richardson, S.H., Erlank, A.J. and Hart, S.R., 1985. Kimberlite-borne garnet peridotite xenoliths from old enriched subcontinental lithosphere: Earth and Planetary Science Letters, 75, p. 116-128.

Kopylova M. G., Russell, J. K., and Cookenboo, H. O., (this volume). Mantle xenoliths of the Jericho kimberlite: Implications for upper mantle stratigraphy and the thermal regime of the Slave Craton, Canada.

Nassichuk, W.W., \& McIntyre, D.J., 1995. Cretaceous and Tertiary fossils discovered in kimberlites at Lac de Gras in the Slave province, Northwest Territories: Geological Survey of Canada Current Research 1995-B, p. 109-114.

Paquette, J.L., Peucat, J.J., Bernard-Griffiths, J., and Marchand, J., 1985. Evidence for old Precambrian relics shown by $\mathrm{U}-\mathrm{Pb}$ zircon dating of eclogites and associated rocks in the Hercynian belt of South Brittany, France: Chemical Geology, 52, p. 203-216.

Paquette, J.L., Monchoux, P., and Couturier, M., 1995. Geochemical and isotopic study of a norite-eclogite transition in the European Variscan belt: Implications for U-Pb zircon systematics in metabasic rocks: Geochimica et Cosmochimica Acta, 59, p. 1611-1622.

Peucat, J.J., Vidal, Ph., Godard, G., and Postaire, B., 1982. Precambrian U-Pb zircon ages in eclogites and garnet pyroxenites from South Brittany (France): an old oceanic crust in the West European Hercynian belt? Earth and Planetary Science Letters, 60, p. 70-78. 